DOI: $10.1590 / 1413-81232010155.12082015$

\title{
É preciso politizar o SUS
}

It is necessary to politicize the SUS

Luiz Carlos de Oliveira Cecilio ${ }^{2}$

\section{Imagens e lembranças}

O cenário é a Escola Nacional de Saúde Pública (ENSP), final da década de oitenta e, ali, encantado, descubro, pelas mãos de seus docentes, entre eles o Mario Hamilton, a Suzana Badino e o próprio Javier, o debate trazido pelo Carlos Matus, que nos "falava" por horas a fio, em um vídeo

${ }^{2}$ Universidade Federal de São Paulo. luizcecilio60@gmail.com 
bastante precário, sobre o Planejamento Estratégico Situacional (PES). Como médico sanitarista engajado na construção de um sonhado sistema de saúde para o nosso país (era época do SUDS!), e trabalhando há uma década com planejamento de nível local ou municipal, aquilo me pareceu uma revelação. Era algo como se o "pessoal da ENSP" tivesse um tesouro nas mãos: os conceitos contidos em uma metodologia de planejamento que nos prometia ajudar a enfrentar a complexidade das situações em que atuávamos. Como dizia o Matus, "a complexidade da realidade exige uma metodologia complexa”. O PES acenava com avanços em relação a tudo o que trabalhávamos - naquele momento e em Campinas - como "planejamento", na verdade uma criativa combinação de técnicas de programação físico-financeira com a participação dos trabalhadores. Participação com programação, era essa a marca do LAPA. E olha que se fazia muita coisa, se organizavam coletivos, se disputava um projeto de política pública, se conquistavam aliados. Mas o PES que eu acabava de conhecer na ENSP tinha como ponto de partida a política e uma sofisticada teoria da produção social que parecia "equacionar" - a partir das bem elaboradas formulações de Karel Kosik -, o velho dilema da relação entre "estrutura" e ação, fazendo o pêndulo inclinar para o lado da ação, da agência, visto que atores, individuais ou coletivos, investidos da capacidade de jogar o grande jogo, podiam acumular poder, adquirir capacidade de governo e, afinal, "transformar as estruturas”. Nada mais sedutor, convenhamos, para quem queria, junto com defesa da política de saúde, construir o país democrático e socialista. Acho, também, que Javier e Beth expressam, nesse artigo, o grande esforço desenvolvido pelos docentes do Departamento de Planejamento da ENSP, na direção da construção de uma teoria de planejamento substantiva adequada ao desafio posto pela reforma sanitária brasileira.

\section{Na prática, o PES é outra coisa}

Sim, enquanto metodologia - paradigma conceitual, "teoria" - o PES nos enriqueceu muito. Nosso pensamento ficou mais elaborado, mais exigente; passamos a olhar o mundo com lentes mais sofisticadas e poderosas. O que não é pouca coisa... No entanto, enquanto método - modo de operar, "tecnologia" de governo - o PES não escapou de um empobrecimento, de uma submissão a uma lógica instrumental, como o Javier já apontou tão bem em sua tese de doutorado. Vivi intensamente esses esforços de operacionalização dos princípios do PES a partir de um projeto ético- político voltado para a construção de um sistema de saúde público, universal e socialmente controlado. O PES, na prática, precisava, é claro, ser adaptado, "simplificado", mas, ao fazermos isso, ele parecia se desencarnar, virar simulacro da sua potência inicial. Qual seria o problema então? Falta de tempo? Falta de técnicos preparados para "aplicar" o método? Ou haveria algo que precisávamos compreender (e valorizar) melhor?

\section{Planejamento ou gestão?}

O próprio Matus se ocupava cada vez mais, nos seus últimos anos, de pensar os "sistemas de direção” ou a gestão do plano, de modo que para ele, gradualmente, a "gestão" subordinou-se ao "planejamento". Tenho a impressão de que, na leitura que fazíamos do PES na época, a gestão era apenas o "quarto momento", que a gente resolveria depois, uma vez feito o plano. A "gestão" como algo subordinado ao "plano", um dos seus instrumentos. Ouso dizer, com a experiência de vinte anos de trabalho com as mais variadas adaptações do PES: o momento tático-operacional era o pântano do plano, o terreno onde perdíamos todas as batalhas. Derrotas que nos desestimulavam e nos faziam descrer, gradativamente, na potência do planejamento como instrumento efetivo de mudança. Onde estava então o problema, já que o PES, como metodologia, era muito elaborado e fomos produzindo, cada vez mais, técnicos com preparo para fazer bons planos? Por que os planos nunca saiam do papel?

\section{Planejamento/gestão e que mais?}

Se bem olhado o texto em debate, vemos como os autores vão agregando ao campo planejamento/gestão novos elementos do campo da Saúde Coletiva (cultura, modelos assistenciais, micropolítica de saúde, humanização, gestão da clínica, etc.), o que, no limite, pediria um novo nome para o campo "planejamento/gestão". Qual? Penso que o termo "planejamento" perdeu muita força na nossa experiência de construção do SUS. O que se planeja hoje no SUS? Qual o modelo de planejamento, enquanto concepção e tecnologia, que está presente no Pacto pela Saúde, além de uma vaga proposição de ser "participativo e ascendente"? Os "eixos” do pacto são tão estruturados, os indicadores tão bem definidos, que, tudo isso, aliado à falta de técnicos no extenso território nacional, faz com que os "planos municipais" acabem assumindo uma normatividade e formalismo que ficam a anos-luz do melhor pensamento de Matus e Testa... Basta lembrar a 
pobreza, a falta de criatividade dos "planos" elaborados pelos municípios durante o processo de municipalização, quando empresas "especializadas" elaboravam o mesmo plano para dezenas de municípios, apenas mudando os dados locais, para cumprir as exigências das normas operacionais (NOB). São raríssimas as experiências municipais, hoje, de o planejamento ser utilizado como elemento politizador, problematizador e promotor de mudanças como pensamos um dia. Os caminhos têm sido outros...

\section{Planejar na estrutura do Estado?}

Isso tudo sem esquecer que os experimentos de inovação nos modos de se fazer o planejamento/ gestão, pelo menos nos quatro "modelos" apontados pelos autores do artigo, foram desenvolvidos em contextos público-governamentais. Tal fato resultava, de saída, em enormes dificuldades operacionais, com atores institucionais operando em baixíssimas condições de governabilidade. Ouso dizer que a baixa governabilidade para conduzir os planos destruía nossa esperança ou a possibilidade de sua utilização como instrumento de mudança. Como fazer planos em contextos de descontinuidade política, de descompromisso e despreparo dos governantes, de subfinanciamento e baixíssimo controle social? Matus dizia que fazer plano era, antes de mais nada, criar governabilidade e, por isso, quanto mais adverso o contexto, mais necessário fazer planos, dar direcionalidade ao barco, não "ser escravos das circunstâncias”. O diabo é que sabíamos disso tudo, mas nada acontecia como queríamos. O que é que a gente estava deixando escapar?

\section{Entre a micropolítica e o estrutural-funcionalismo}

Estava cada vez mais claro que um importante desafio teórico e político que tínhamos pela frente era alcançar uma melhor compreensão do singular funcionamento das organizações de saúde, em particular o quanto elas têm uma vida própria, uma micropolítica marcada pelo autogovernos dos seus trabalhadores. Por tudo isso, é possível dizer que o planejamento foi perdendo força como instrumento de luta e mudança, em particular a forte aposta que fizemos no seu caráter instituinte. Daí que muitos de nós que viemos do campo do "planejamento" fomos ficando cada vez mais "micropolíticos", ligados nos espaços de produção do cuidado, encarando tanto temas como subjetividade, mas também a questão do poder e das relações que atravessam e produzem as organizações. Passamos a nos ocupar mais da "gestão" do que do "planejamento" em si. Ao mesmo tempo, temos visto o triunfo (?) de um pensamento fortemente funcionalista na abordagem das organizações, no contexto do acachapante processo de terceirizações, privatizações e surgimento do Estado-empresário - na expressão do Boaventura dos Santos -, que temos vivido neste século. Junto com esta "reforma do Estado", foi se impondo o gerencialismo, dado como solução para nossas mazelas de "gestão". O gerencialismo (a importação de princípios e métodos de gestão do setor privado para o setor público) foi se impondo como um "discurso de consenso". O gerencialismo representa o triunfo de uma razão fortemente instrumental (a adequação dos meios aos fins), que tem como eixo central a funcionalização da força de trabalho. "Gestão de pessoas" é a tradução acabada de tal concepção. O gerencialismo é a despolitização do SUS. É o reverso de nossa tradição de considerar a politização da nossa força de trabalho, no sentido substantivo do termo, como essencial para a construção do SUS!

\section{Para finalizar}

Está-se falando do quê quando se diz planejamento/gestão no SUS hoje? Que "planejamento" e para quê? Que "gestão" e para quê? Acho que precisamos retomar a vitalidade de pensadores como Testa e Matus, e que a ENSP teve um papel fundamental de divulgação nas últimas décadas. O movimento social de Campinas acaba de impor recente derrota à SPDM(Sociedade Paulista para o Desenvolvimento da Medicina), grupo privado que atua de modo agressivo na saúde, ao negar a renovação do contrato para que continue fazendo a administração do Complexo Hospitalar Ouro Verde, um equipamento de excelência, conquista do movimento sanitário campineiro e construído totalmente com recursos públicos, mas com "gestão privada" seguindo "tendências” atuais. Não é uma vitória consolidada, mas um primeiro passo foi dado, colocando na ordem do dia a importância do controle social no SUS. Pensar, então, a política como o necessário abraço do "macro", da grande política, da luta junto aos atores políticos que formulam e disputam políticas, com o "micropolítico", irredutível espaço de disputa de um novo modo de se produzir cuidado e cidadania.

Voltemos a fazer política! O SUS está precisando de "choque de política" e não de "choque de gestão”! 